Supplement of Earth Syst. Sci. Data, 13, 671-696, 2021

https://doi.org/10.5194/essd-13-671-2021-supplement

(c) Author(s) 2021. This work is distributed under

the Creative Commons Attribution 4.0 License.

(c) (1)

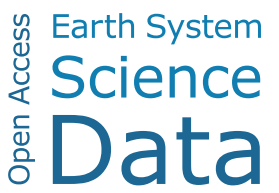

Supplement of

\title{
A novel hydrographic gridded data set for the northern Antarctic Penin- sula
}

\section{Tiago S. Dotto et al.}

Correspondence to: Tiago S. Dotto (t.segabinazzi-dotto@uea.ac.uk), Mauricio M. Mata (mauricio.mata@furg.br), Rodrigo Kerr (rodrigokerr@furg.br), and Carlos A. E. Garcia (dfsgar@furg.br)

The copyright of individual parts of the supplement might differ from the CC BY 4.0 License. 

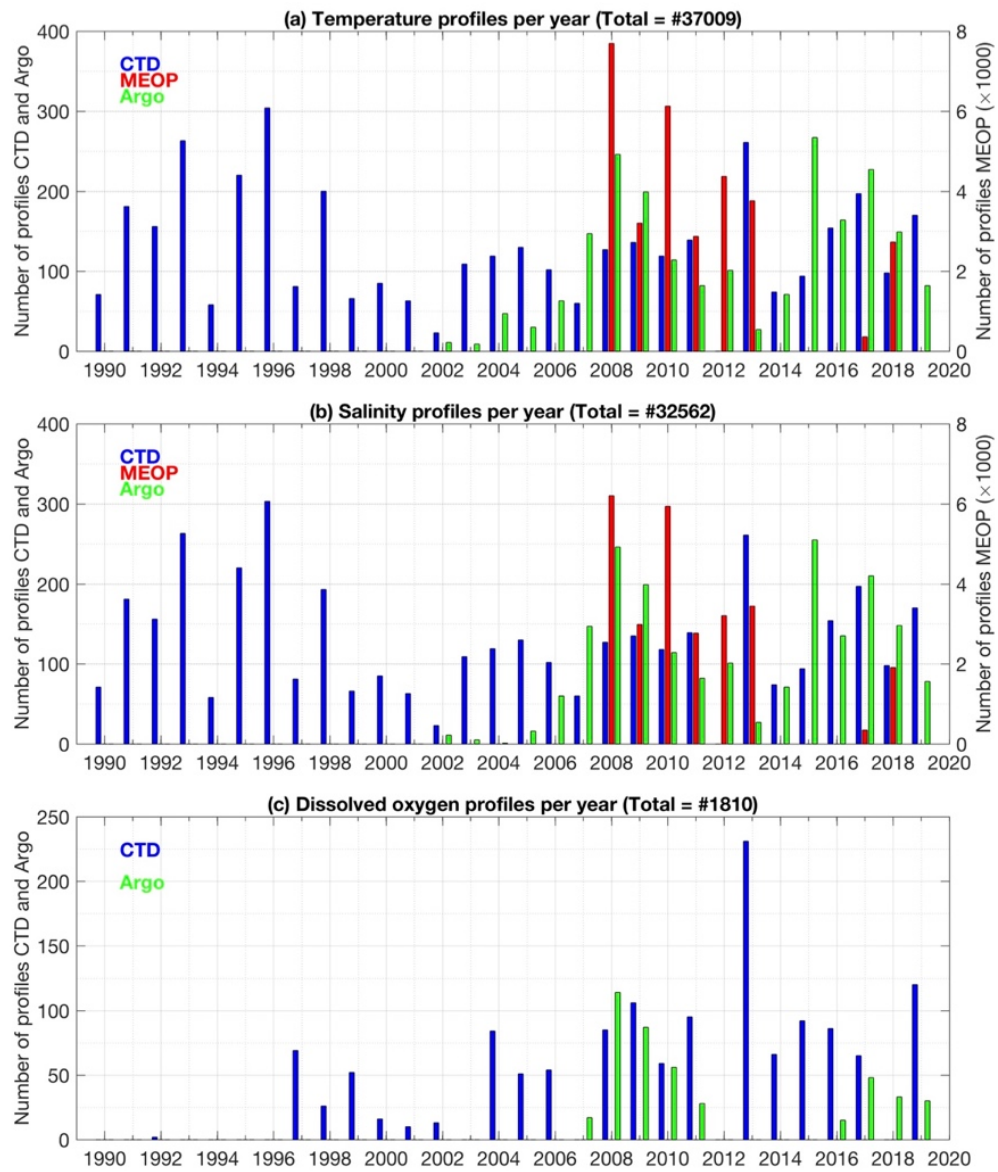

Figure S1. (a) Number of in situ temperature profiles per year according to each platform (CTD in blue, MEOP in red and Argo in green). Note the different y-axis for CTD/Argo (left) and MEOP (right). (b) Same as panel (a), but for practical salinity. (c) Same as panel (a), but for dissolved oxygen. MEOP platforms do not carry oxygen sensors. Note the different scale of dissolved oxygen compared to in situ temperature and practical salinity. Total number of profiles for the period in shown in each panel title. 

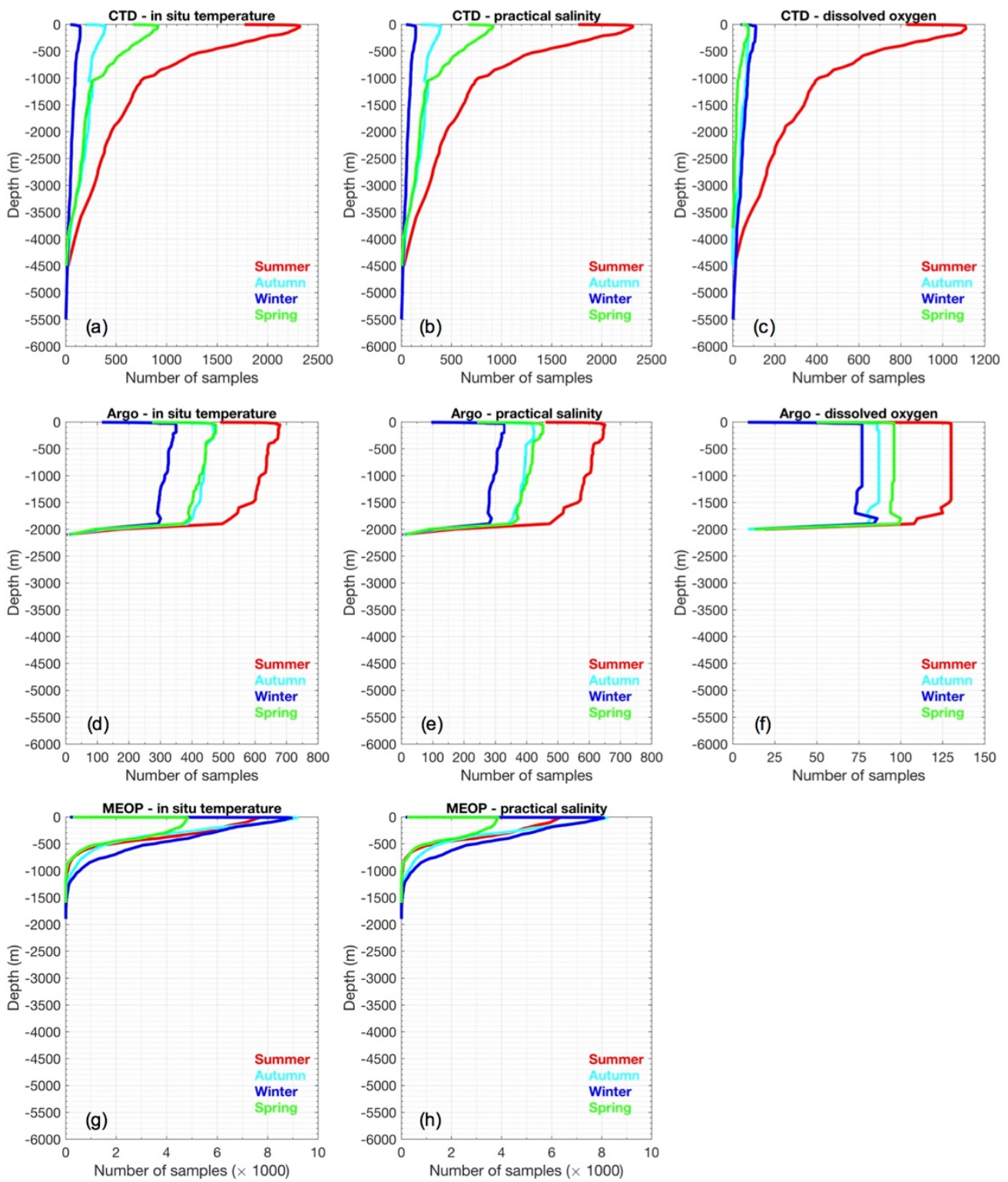

Figure S2. Number of samples per depth for summer (red), autumn (cyan), winter (blue) and spring (green). (a) In situ temperature, (b) practical salinity and (c) dissolved oxygen for CTD. (d) In situ temperature, (e) practical salinity and (f) dissolved oxygen for Argo. (g) In situ temperature and (h) practical salinity for MEOP. Note the different $\mathrm{x}$-axis among the panels. 

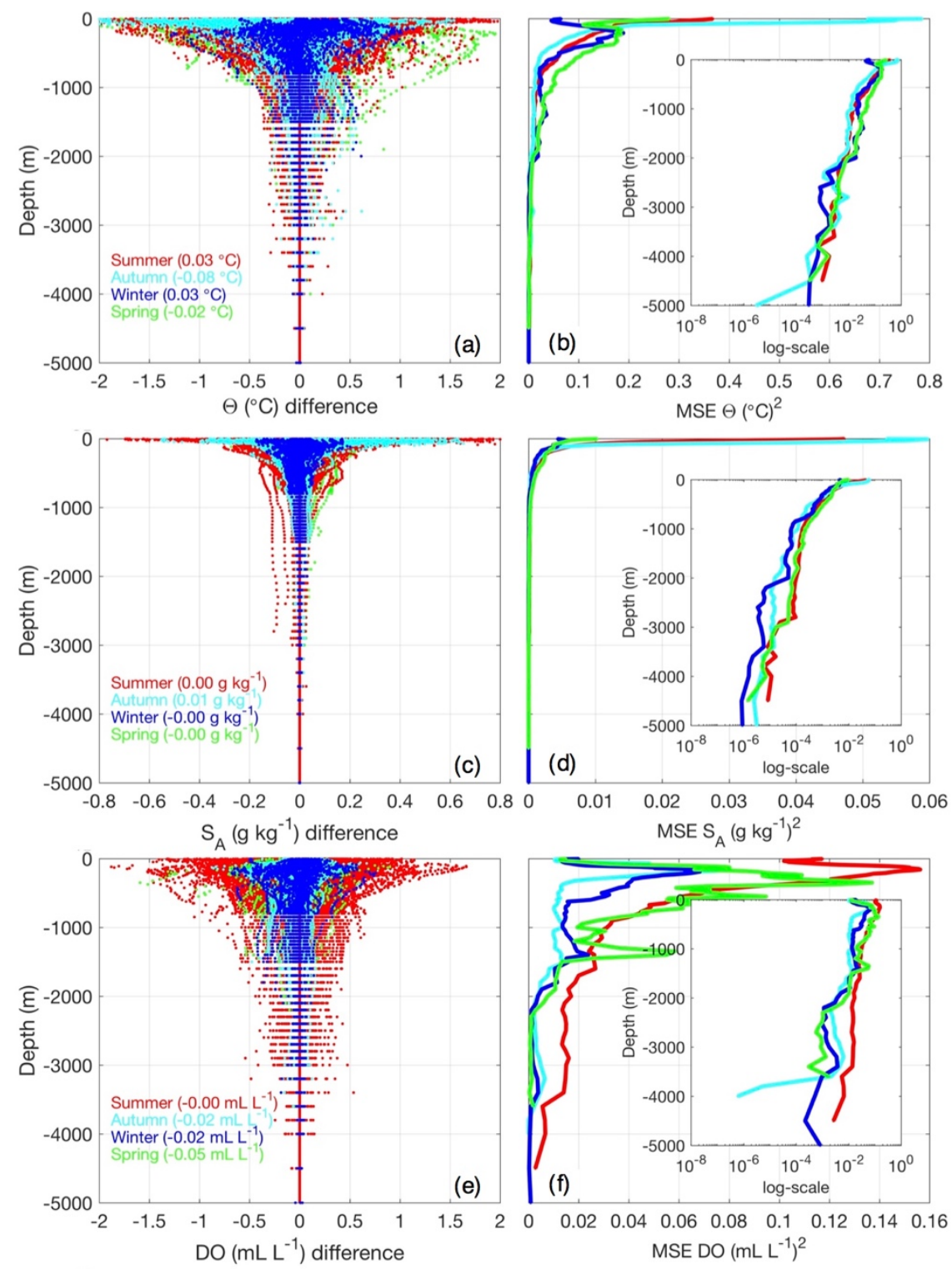

Figure S3. (a) Conservative temperature $\left(\Theta ;{ }^{\circ} \mathrm{C}\right)$ vertical difference between the NAPv1.0 and CTD stations closer $\sim 6 \mathrm{~km}$ to the grid points for summer (red), autumn (cyan), winter (blue) and spring (green). Average difference for the water column in shown in parenthesis according to the respective colours. (b) Mean squared error (MSE) between the NAPv1.0 and the CTD stations closer $\sim 6 \mathrm{~km}$ for $\Theta$. Inset shows the base 10 logarithmic scale in the x-axis. (c) Same as panel (a), but for absolute salinity $\left(\mathrm{S}_{\mathrm{A}} ; \mathrm{g} \mathrm{kg}^{-1}\right)$. (d) Same as panel (b), but for $\mathrm{S}_{\mathrm{A}}$. (e) Same as panel (a), but for dissolved oxygen (DO; $\mathrm{mL} \mathrm{L}^{-1}$ ). (d) Same as panel (b), but for DO. 

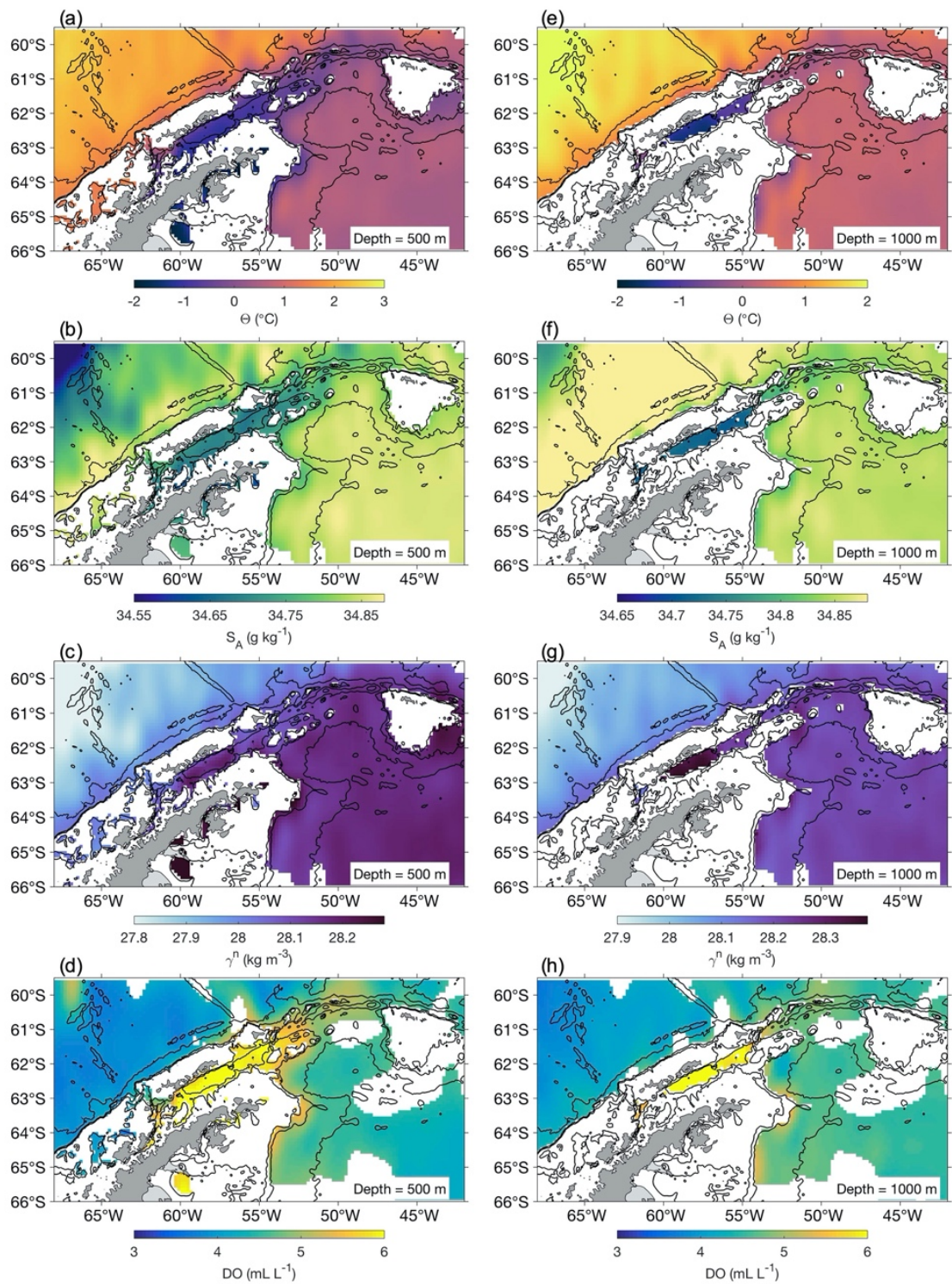

Figure S4. Summer surface maps of NAPv1.0 at $500 \mathrm{~m}$ (left panels) and $1000 \mathrm{~m}$ (right panels) depth. (a and e) Conservative temperature $\left(\Theta ;{ }^{\circ} \mathrm{C}\right)$. (b and f) Absolute salinity $\left(\mathrm{S}_{\mathrm{A}}, \mathrm{g} \mathrm{kg}^{-1}\right)$. (c and g) Neutral density $\left(\gamma^{\mathrm{n}} ; \mathrm{kg} \mathrm{m}^{-3}\right)$. ( $\mathrm{d}$ and h) Dissolved oxygen (DO; $\mathrm{mL} \mathrm{L}^{-1}$ ). ETOPO1 isobaths of $500 \mathrm{~m}, 1000 \mathrm{~m}, 3000 \mathrm{~m}$ and $5000 \mathrm{~m}$ are depicted by the black lines. Coastline from SCAR Antarctic Digital Database. 

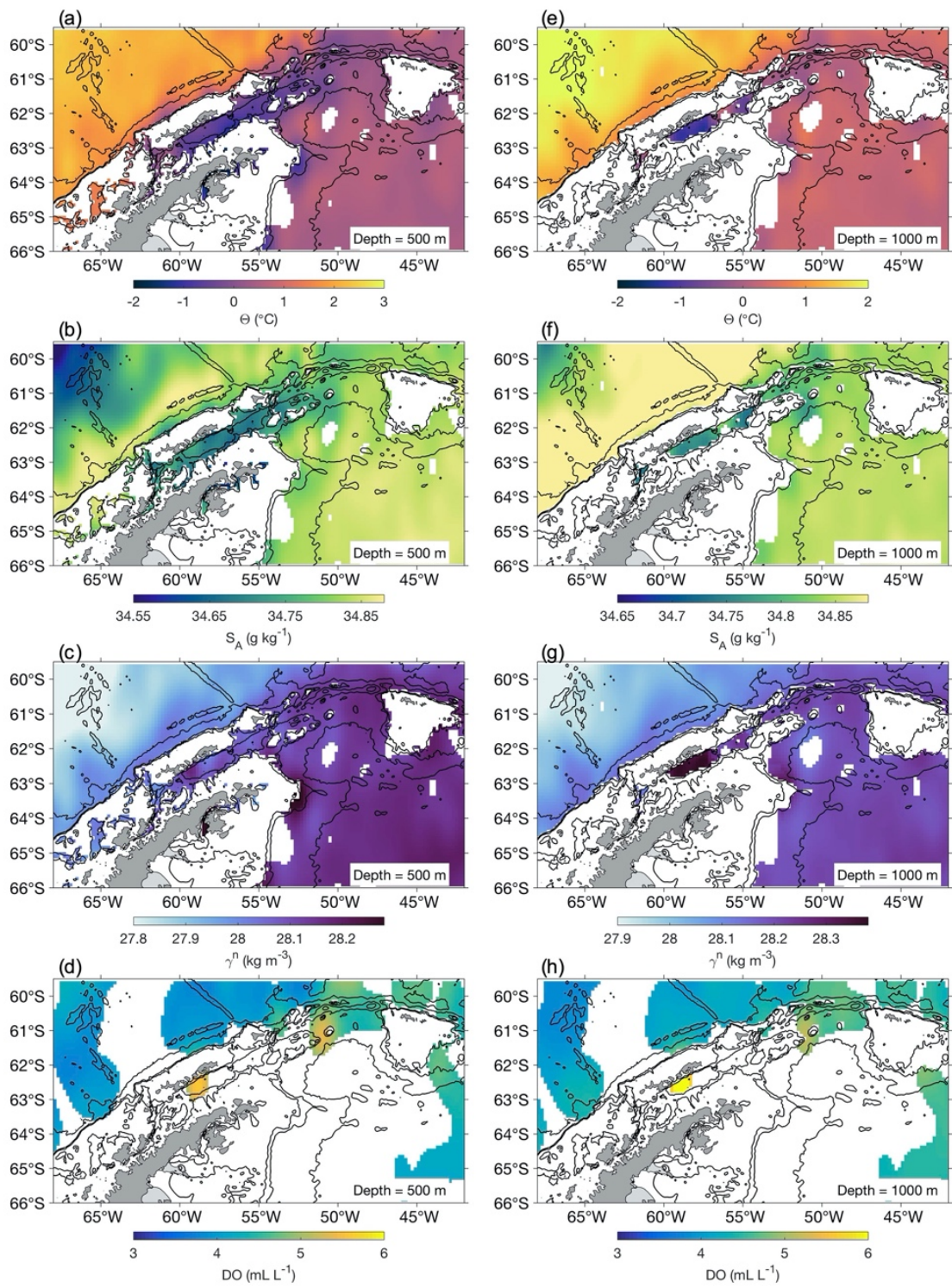

Figure S5. Same as Figure S4, but for autumn. 

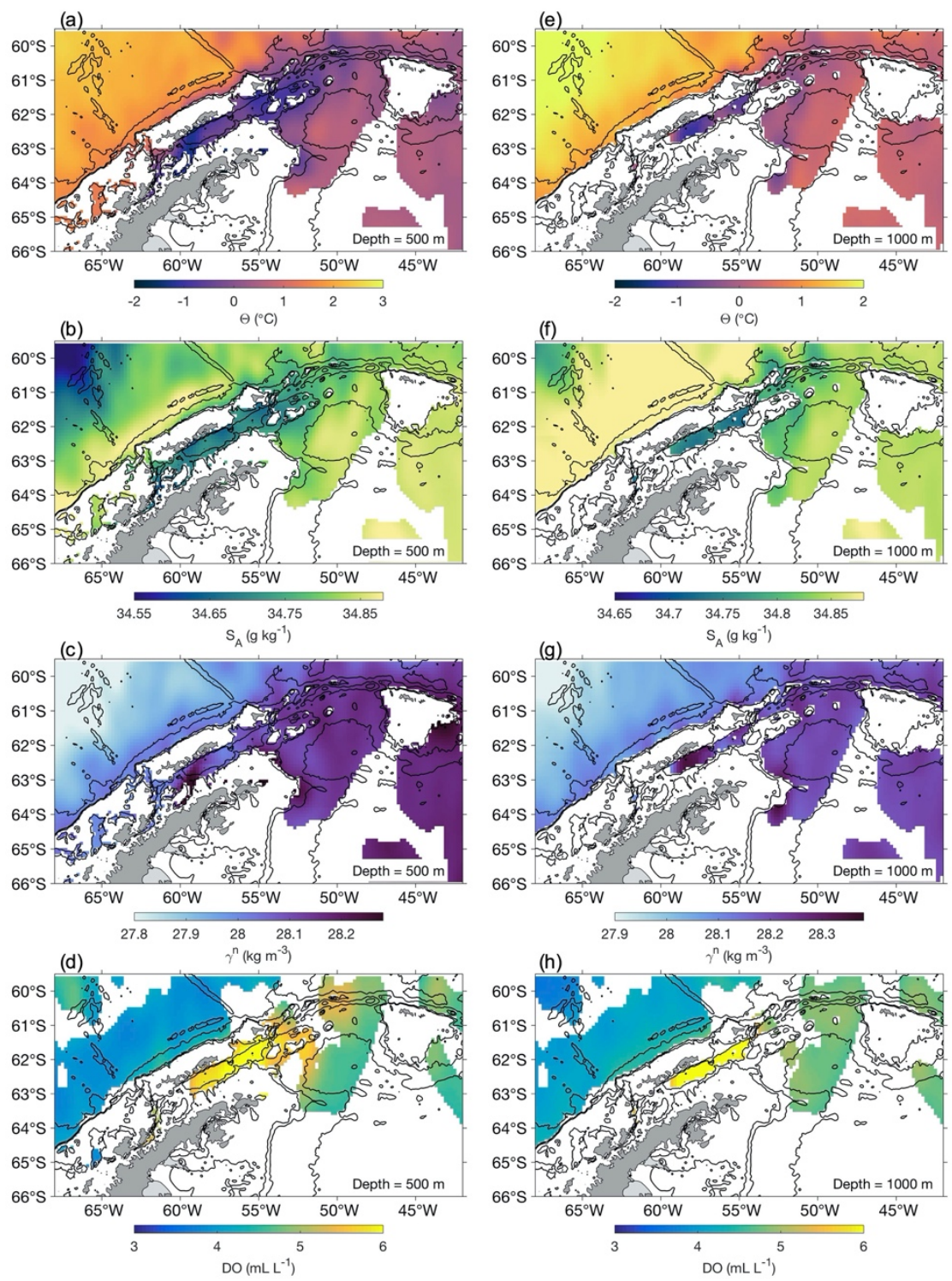

Figure S6. Same as Figure S4, but for winter. 

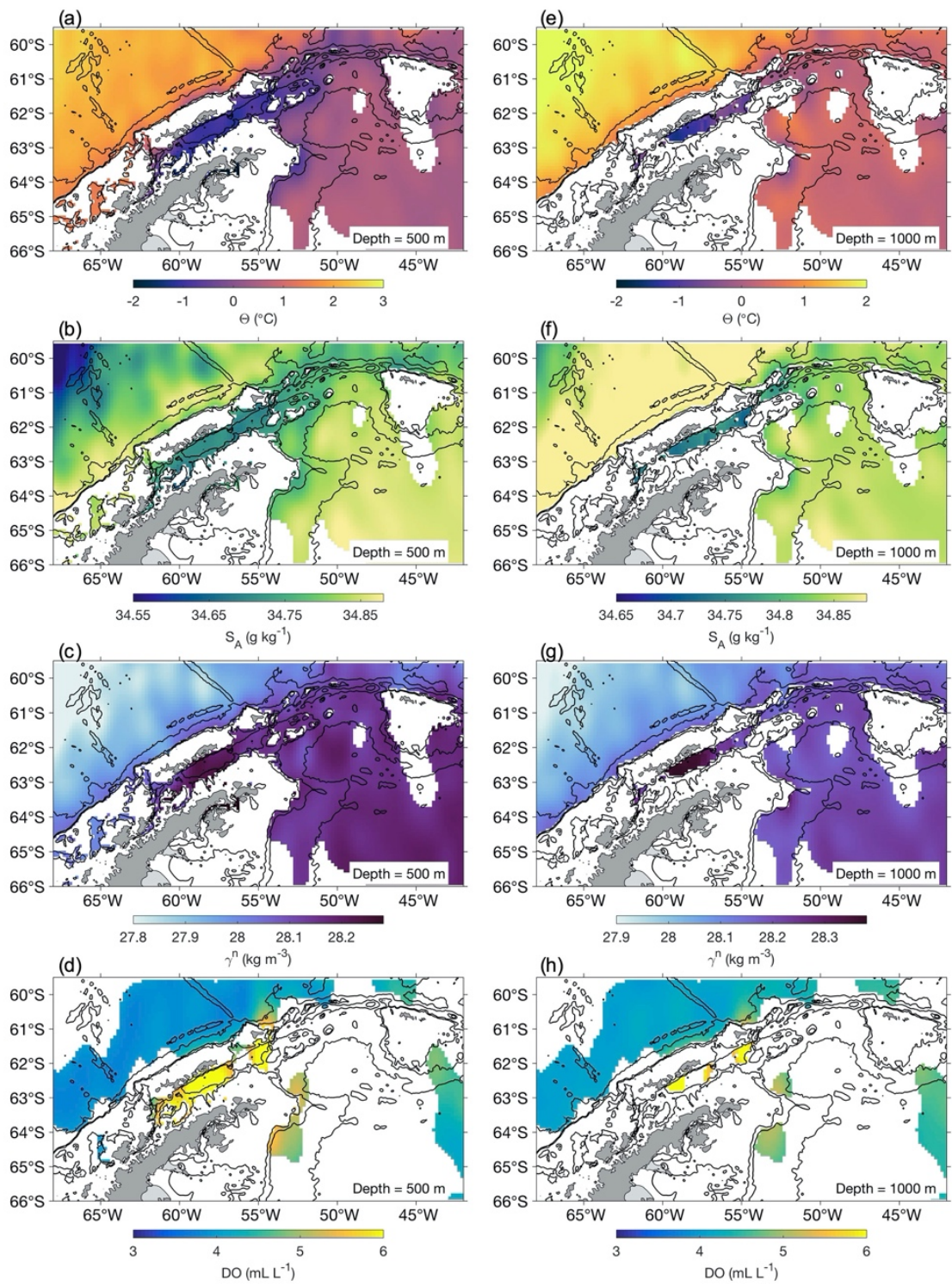

Figure S7. Same as Figure S4, but for spring. 

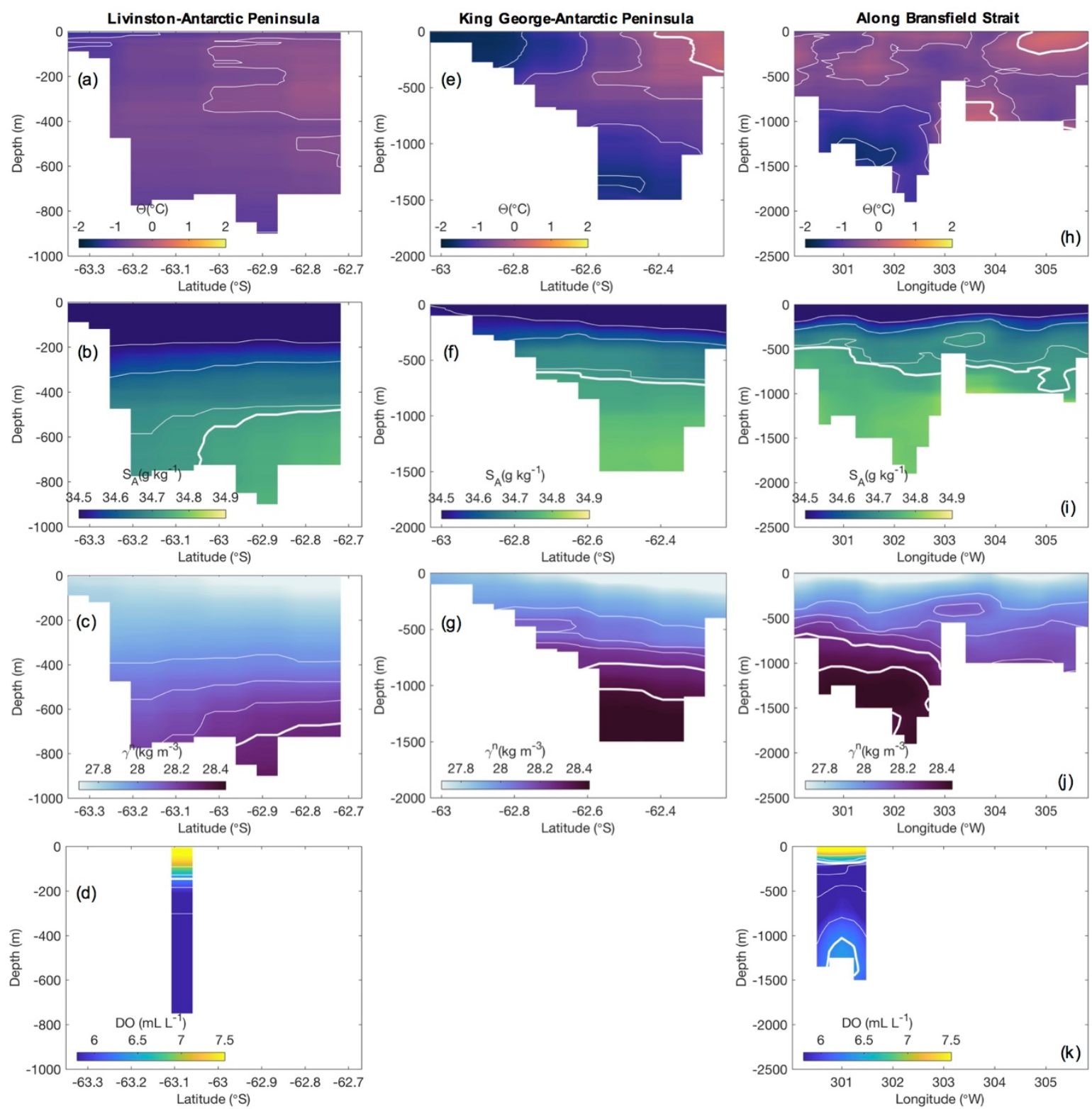

Figure S8. Autumn vertical sections crossing the Bransfield Strait between the Livingston Island and the Antarctic Peninsula (a-d; red line in Fig. 1a), King George Island and the Antarctic Peninsula (e-g; blue line in Fig. 1a), and along the Bransfield Strait (h-k; black line in Fig. 1a). Conservative temperature $\left(\Theta ;{ }^{\circ} \mathrm{C}\right)$ is shown in panels (a), (e) and (h). Isotherm of $0^{\circ} \mathrm{C}$ is shown by the thick white line. Thin lines show the isotherms of $-1.5^{\circ} \mathrm{C}$ to $-0.5^{\circ} \mathrm{C}$ every $0.5^{\circ} \mathrm{C}$. Absolute salinity $\left(\mathrm{S}_{\mathrm{A}} ; \mathrm{g} \mathrm{kg}^{-1}\right)$ is shown in panels (b), (f) and (i). Isoline of $34.72 \mathrm{~g} \mathrm{~kg}^{-1}$ is shown by the thick white line. Thin lines show the isolines of 34.5 to $34.7 \mathrm{~g} \mathrm{~kg}^{-1}$ every $0.1 \mathrm{~g} \mathrm{~kg}^{-1}$. Neutral density $\left(\gamma^{\mathrm{n}} ; \mathrm{kg} \mathrm{m}^{-3}\right)$ is shown in panels (c), (g) and (j). The isolines of 28.27 and 28.40 $\mathrm{kg} \mathrm{m}^{-3}$ are shown by the thick white lines. Thin lines show the isolines of 28.00 to $28.20 \mathrm{~kg} \mathrm{~m}^{-3}$ every $0.1 \mathrm{~kg} \mathrm{~m}^{-3}$. Dissolved oxygen (DO; $\mathrm{mL} \mathrm{L}^{-1}$ ) is shown in panels $(\mathrm{d})$ and $(\mathrm{k})$. The isolines of $6.3 \mathrm{~mL} \mathrm{~L}^{-1}$ is shown by the thick white lines. Thin lines show the isolines of 5.5 to $7.0 \mathrm{~mL} \mathrm{~L}^{-1}$ every $0.5 \mathrm{~mL} \mathrm{~L}^{-1}$. Note the difference in the depth ranges. Contrarily to Figure 8 , this figure was created by simply selecting the nearest grid points to the sections, due to the limited amount of data in other seasons except summer. 

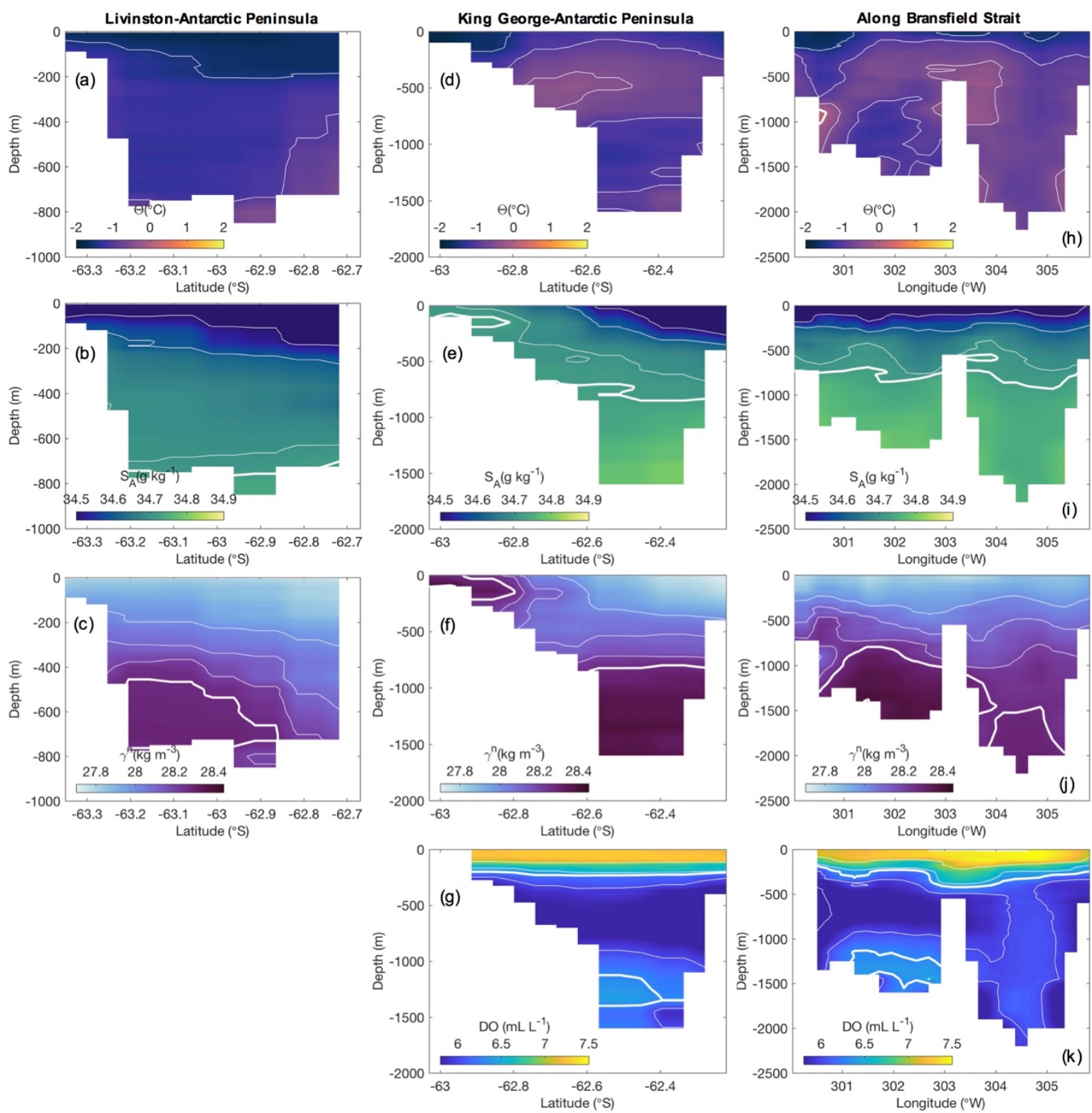

Figure S9. Winter vertical sections crossing the Bransfield Strait between the Livingston Island and the Antarctic Peninsula (a-c; red line in Fig. 1a), King George Island and the Antarctic Peninsula (d-g; blue line in Fig. 1a), and along the Bransfield Strait (h-k; black line in Fig. 1a). Conservative temperature $\left(\Theta ;{ }^{\circ} \mathrm{C}\right)$ is shown in panels (a), (d) and (h). Isotherm of $0^{\circ} \mathrm{C}$ is shown by the thick white line. Thin lines show the isotherms of $-1.5^{\circ} \mathrm{C}$ to $-0.5^{\circ} \mathrm{C}$ every $0.5^{\circ} \mathrm{C}$. Absolute salinity $\left(\mathrm{S}_{\mathrm{A}} ; \mathrm{g} \mathrm{kg}^{-1}\right)$ is shown in panels (b), (e) and (i). Isoline of $34.72 \mathrm{~g} \mathrm{~kg}^{-1}$ is shown by the thick white line. Thin lines show the isolines of 34.5 to $34.7 \mathrm{~g} \mathrm{~kg}^{-1}$ every $0.1 \mathrm{~g} \mathrm{~kg}^{-1}$. Neutral density $\left(\gamma^{\mathrm{n}} ; \mathrm{kg} \mathrm{m}^{-3}\right)$ is shown in panels (c), (f) and (j). The isoline of 28.27 is shown by the thick white lines. Thin lines show the isolines of 28.00 to $28.20 \mathrm{~kg} \mathrm{~m}^{-3}$ every $0.1 \mathrm{~kg} \mathrm{~m}^{-3}$. Dissolved oxygen (DO; mL $\left.\mathrm{L}^{-1}\right)$ is shown in panels $(\mathrm{g})$ and $(\mathrm{k})$. The isolines of $6.3 \mathrm{~mL} \mathrm{~L}^{-1}$ is shown by the thick white lines. Thin lines show the isolines of 5.5 to $7.0 \mathrm{~mL} \mathrm{~L}^{-1}$ every $0.5 \mathrm{~mL} \mathrm{~L}^{-1}$. Note the difference in the depth ranges. Contrarily to Figure 8 , this figure was created by simply selecting the nearest grid points to the sections, due to the limited amount of data in other seasons except summer. 

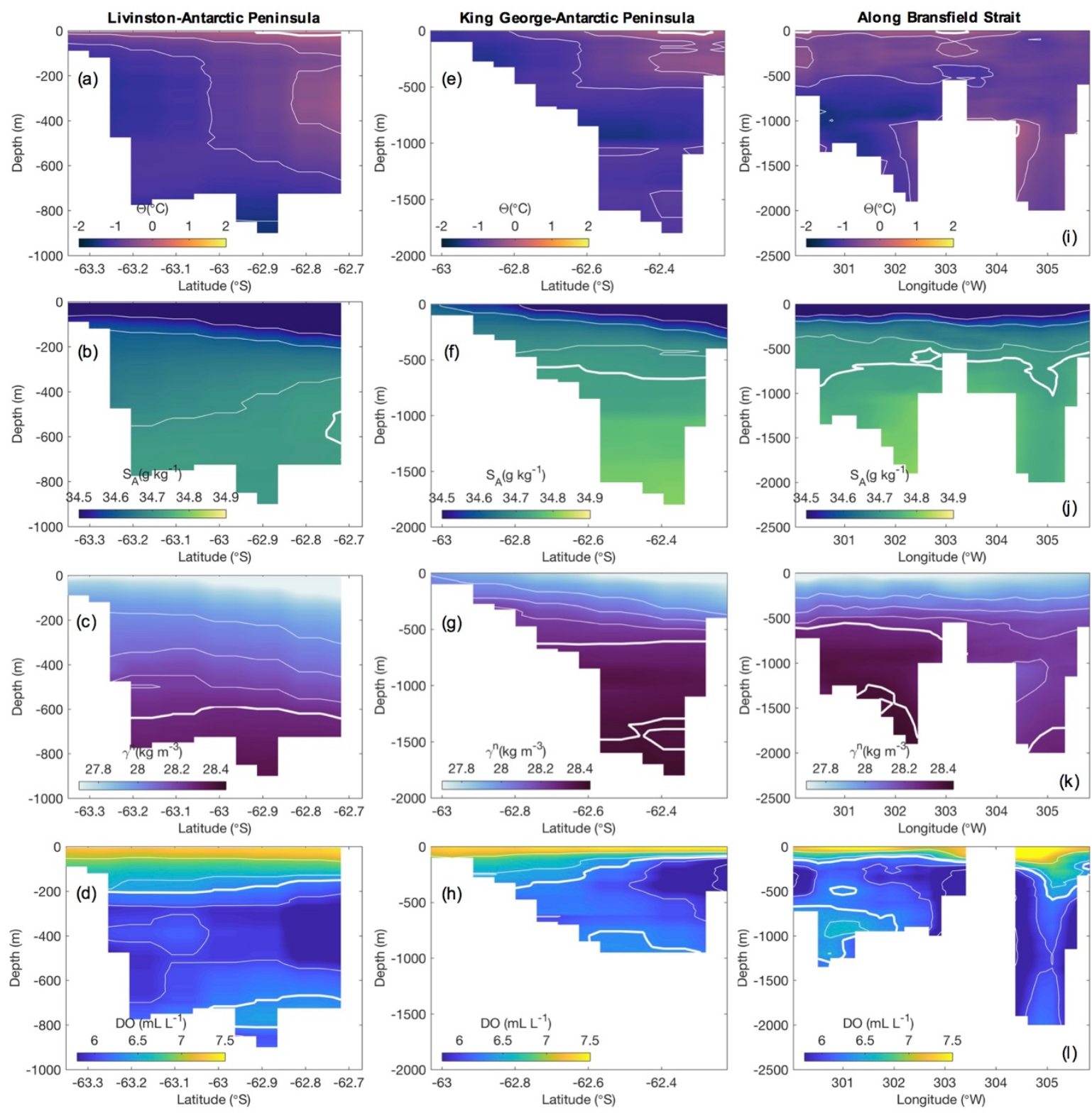

Figure S10. Spring vertical sections crossing the Bransfield Strait between the Livingston Island and the Antarctic Peninsula (a-d; red line in Fig. 1a), King George Island and the Antarctic Peninsula (e-h; blue line in Fig. 1a), and along the Bransfield Strait (i-l; black line in Fig. 1a). Conservative temperature $\left(\Theta ;{ }^{\circ} \mathrm{C}\right)$ is shown in panels (a), (e) and (i). Isotherm of $0^{\circ} \mathrm{C}$ is shown by the thick white line. Thin lines show the isotherms of $-1.5^{\circ} \mathrm{C}$ to $+1.5^{\circ} \mathrm{C}$ every $0.5^{\circ} \mathrm{C}$. Absolute salinity $\left(\mathrm{S}_{\mathrm{A}} ; \mathrm{g} \mathrm{kg}^{-1}\right)$ is shown in panels (b), (f) and (j). Isoline of $34.72 \mathrm{~g} \mathrm{~kg}^{-1}$ is shown by the thick white line. Thin lines show the isolines of 34.5 and 34.7 $\mathrm{g} \mathrm{kg}^{-1}$ every $0.1 \mathrm{~g} \mathrm{~kg}^{-1}$. Neutral density $\left(\gamma^{\mathrm{n}} ; \mathrm{kg} \mathrm{m}^{-3}\right)$ is shown in panels $(\mathrm{c}),(\mathrm{g})$ and $(\mathrm{k})$. The isolines of 28.27 and $28.40 \mathrm{~kg} \mathrm{~m}^{-3}$ are shown by the thick white lines. Thin lines show the isolines of 28.00 and $28.20 \mathrm{~kg} \mathrm{~m}^{-3}$ every $0.1 \mathrm{~kg} \mathrm{~m}^{-3}$. Dissolved oxygen (DO; $\mathrm{mL} \mathrm{L}^{-1}$ ) is shown in panels (d), (h) and (l). The isolines of $6.3 \mathrm{~mL} \mathrm{~L}^{-1}$ is shown by the thick white lines. Thin lines show the isolines of 5.5 and $7.0 \mathrm{~mL} \mathrm{~L}^{-1}$ every $0.5 \mathrm{~mL} \mathrm{~L}^{-1}$. Note the difference in the depth ranges. Contrarily to Figure 8 , this figure was created by simply selecting the nearest grid points to the sections, due to the limited amount of data in other seasons except summer. 

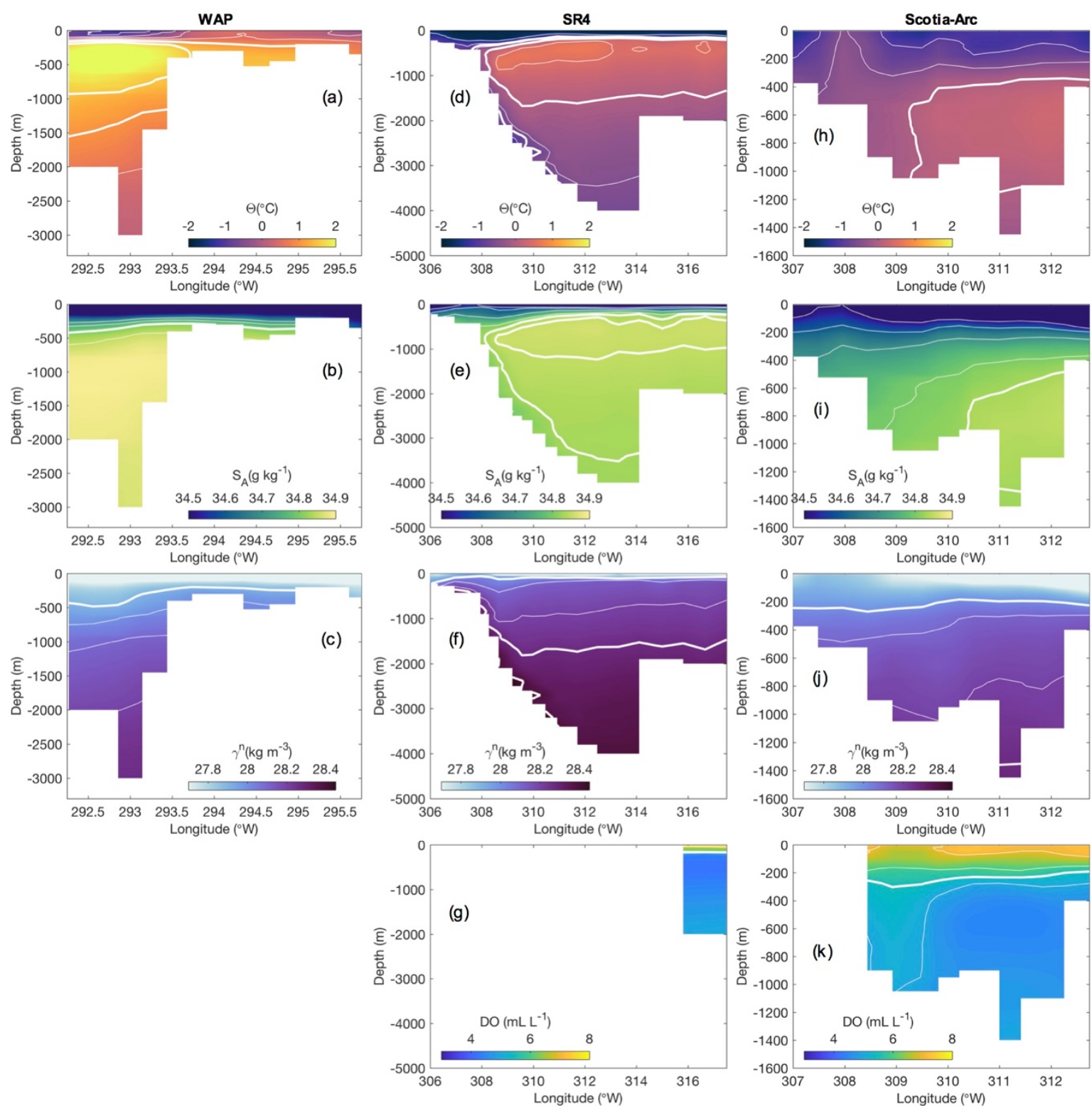

Figure S11. Autumn vertical sections along the Western Antarctic Peninsula (WAP; a-c; magenta line in Fig. 1a), WOCE SR4 across the Weddell Gyre (d-g; green line in Fig. 1a), and Scotia-Arc line over the South Scotia Ridge (h-k; cyan line in Fig. 1a). (a) Conservative temperature $\left(\Theta ;{ }^{\circ} \mathrm{C}\right)$ with isotherms of $1{ }^{\circ} \mathrm{C}$ and $1.5^{\circ} \mathrm{C}\left(-1.5^{\circ} \mathrm{C}\right.$ to $1.5^{\circ} \mathrm{C}$ every $\left.0.5^{\circ} \mathrm{C}\right)$ shown by the thick (thin) white line. (b) Absolute salinity $\left(\mathrm{S}_{\mathrm{A}} ; \mathrm{g} \mathrm{kg}^{-1}\right)$ with isoline of $34.8 \mathrm{~g} \mathrm{~kg}^{-1}\left(34.7 \mathrm{~g} \mathrm{~kg}^{-1}\right.$ to $34.85 \mathrm{~g} \mathrm{~kg}^{-1} \mathrm{every}_{\left.0.05 \mathrm{~g} \mathrm{~kg}^{-1}\right)}$ shown by the thick (thin) white line. (c) Neutral density $\left(\gamma^{\mathrm{n}} ; \mathrm{kg} \mathrm{m}^{-3}\right)$ with isoline of $27.9 \mathrm{~kg} \mathrm{~m}^{-3}\left(28.0 \mathrm{~kg} \mathrm{~m}^{-3}\right.$ to $28.2 \mathrm{~g} \mathrm{~kg}^{-1}$ every $0.1 \mathrm{~kg} \mathrm{~m}^{-3}$ ) shown by the thick (thin) white line. (d) $\Theta$ with isotherms of $-0.7^{\circ} \mathrm{C}$ and $0^{\circ} \mathrm{C}\left(-1.5^{\circ} \mathrm{C}\right.$ to $0.5^{\circ} \mathrm{C}$ every $\left.0.5^{\circ} \mathrm{C}\right)$ shown by the thick (thin) white line. (e) $\mathrm{S}_{\mathrm{A}}$ with isolines of $34.83 \mathrm{~g} \mathrm{~kg}^{-1}$ and $34.85 \mathrm{~g} \mathrm{~kg}^{-1}\left(34.5 \mathrm{~g} \mathrm{~kg}^{-1}\right.$ to $34.8 \mathrm{~g} \mathrm{~kg}^{-1} \mathrm{every}^{0} .1$ $\left.\mathrm{g} \mathrm{kg}^{-1}\right)$ shown by the thick (thin) white line. (f) $\gamma^{\mathrm{n}}$ with isolines of $28.0 \mathrm{~kg} \mathrm{~m}^{-3}, 28.27 \mathrm{~kg} \mathrm{~m}^{-3}$ and $28.4 \mathrm{~kg} \mathrm{~m}^{-3}\left(28.1 \mathrm{~kg} \mathrm{~m}^{-3}\right.$ and $28.2 \mathrm{~kg} \mathrm{~m}^{-3}$ ) shown by the thick (thin) white line. (g) Dissolved oxygen (DO; mL L-1) with isoline of $5.5 \mathrm{~mL} \mathrm{~L}^{-1}\left(5 \mathrm{~mL} \mathrm{~L}^{-1}\right.$ to $7 \mathrm{~mL} \mathrm{~L}^{-1}$ every $1 \mathrm{~mL} \mathrm{~L}^{-1}$ ) shown by the thick (thin) white line. (h) $\Theta$ with isotherms of $0^{\circ} \mathrm{C}\left(-1.0^{\circ} \mathrm{C}\right.$ and $\left.-0.5^{\circ} \mathrm{C}\right)$ shown by the thick (thin) white line. (i) $\mathrm{S}_{\mathrm{A}}$ with isoline of $34.83 \mathrm{~g} \mathrm{~kg}^{-1}\left(34.5 \mathrm{~g} \mathrm{~kg}^{-1}\right.$ to $34.8 \mathrm{~g} \mathrm{~kg}^{-1}$ every $\left.0.1 \mathrm{~g} \mathrm{~kg}^{-1}\right)$ shown by the thick (thin) white line. (j) $\gamma^{\mathrm{n}}$ with isolines of $28.0 \mathrm{~kg} \mathrm{~m}^{-3}$ and $28.27 \mathrm{~kg} \mathrm{~m}^{-3}\left(28.1 \mathrm{~kg} \mathrm{~m}^{-3}\right.$ and $\left.28.2 \mathrm{~kg} \mathrm{~m}^{-3}\right)$ shown by the thick (thin) white line. (k) Dissolved oxygen (DO; $\left.\mathrm{mL} \mathrm{L}^{-1}\right)$ with isoline of $5.5 \mathrm{~mL} \mathrm{~L}^{-1}\left(5 \mathrm{~mL} \mathrm{~L}^{-1}\right.$ to $7 \mathrm{~mL} \mathrm{~L}^{-1}$ every $\left.1 \mathrm{~mL} \mathrm{~L}^{-1}\right)$ shown by the thick (thin) white line. Contrarily to Figure 9, this figure was created by simply selecting the nearest grid points to the sections, due to the limited amount of data in other seasons except summer. 

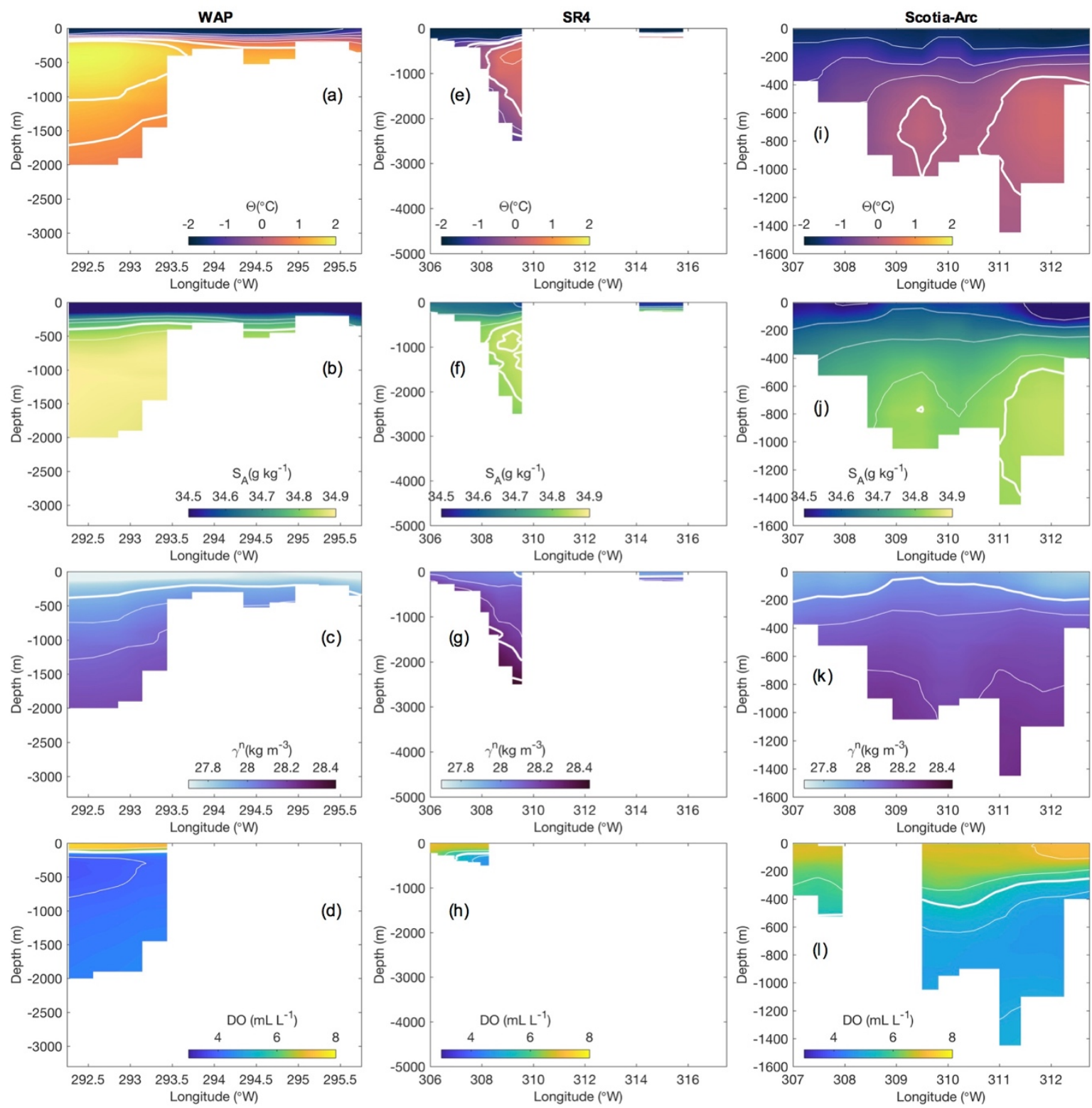

Figure S12. Winter vertical sections along the Western Antarctic Peninsula (WAP; a-d; magenta line in Fig. 1a), WOCE SR4 across the Weddell Gyre (e-h; green line in Fig. 1a), and Scotia-Arc line over the South Scotia Ridge (i-l; cyan line in Fig. 1a). (a) Conservative temperature $\left(\Theta ;{ }^{\circ} \mathrm{C}\right)$ with isotherms of $1^{\circ} \mathrm{C}$ and $1.5^{\circ} \mathrm{C}\left(-1.5^{\circ} \mathrm{C}\right.$ to $0.5^{\circ} \mathrm{C}$ every $\left.0.5^{\circ} \mathrm{C}\right)$ shown by the thick (thin) white line. (b) Absolute salinity $\left(\mathrm{S}_{\mathrm{A}} ; \mathrm{g} \mathrm{kg}^{-1}\right)$ with isoline of $34.8 \mathrm{~g} \mathrm{~kg}^{-1}\left(34.7 \mathrm{~g} \mathrm{~kg}^{-1}\right.$ to $34.85 \mathrm{~g} \mathrm{~kg}^{-1}$ every $\left.0.05 \mathrm{~g} \mathrm{~kg}^{-1}\right)$ shown by the thick (thin) white line. (c) Neutral density $\left(\gamma^{\mathrm{n}} ; \mathrm{kg} \mathrm{m}^{-3}\right)$ with isoline of $27.9 \mathrm{~kg} \mathrm{~m}^{-3}\left(28.0 \mathrm{~kg} \mathrm{~m}^{-3}\right.$ and $\left.28.1 \mathrm{~kg} \mathrm{~m}^{-3}\right)$ shown by the thick (thin) white line. (d) Dissolved oxygen (DO; $\mathrm{mL} \mathrm{L}^{-1}$ ) with isoline of $5.5 \mathrm{~mL} \mathrm{~L}^{-1}\left(4 \mathrm{~mL} \mathrm{~L}^{-1}\right.$ to $7 \mathrm{~mL} \mathrm{~L}^{-1}$ every $1 \mathrm{~mL}$ $\left.\mathrm{L}^{-1}\right)$ shown by the thick (thin) white line. (e) $\Theta$ with isotherms of $-0.7^{\circ} \mathrm{C}$ and $0^{\circ} \mathrm{C}\left(-1.5^{\circ} \mathrm{C}\right.$ to $0.5^{\circ} \mathrm{C}$ every $\left.0.5^{\circ} \mathrm{C}\right)$ shown by the thick (thin) white line. (f) $\mathrm{S}_{\mathrm{A}}$ with isolines of $34.83 \mathrm{~g} \mathrm{~kg}^{-1}$ and $34.85 \mathrm{~g} \mathrm{~kg}^{-1}\left(34.6 \mathrm{~g} \mathrm{~kg}^{-1}\right.$ to $34.8 \mathrm{~g} \mathrm{~kg}^{-1}$ every $\left.0.1 \mathrm{~g} \mathrm{~kg}^{-1}\right)$ shown by the thick (thin) white line. $(\mathrm{g}) \gamma^{\mathrm{n}}$ with isolines of $28.0 \mathrm{~kg} \mathrm{~m}^{-3}, 28.27 \mathrm{~kg} \mathrm{~m}^{-3}$ and $28.4 \mathrm{~kg} \mathrm{~m}^{-3}\left(28.1 \mathrm{~kg} \mathrm{~m}^{-3}\right.$ and $\left.28.2 \mathrm{~kg} \mathrm{~m}^{-3}\right)$ shown by the thick (thin) white line. (h) Dissolved oxygen (DO; $\left.\mathrm{mL} \mathrm{L}^{-1}\right)$ with isoline of $5.5 \mathrm{~mL} \mathrm{~L}^{-1}\left(5 \mathrm{~mL} \mathrm{~L}^{-1}\right.$ and $\left.6 \mathrm{~mL} \mathrm{~L}^{-1}\right)$ shown by the thick (thin) white line. (i) $\Theta$ with isotherms of $0^{\circ} \mathrm{C}\left(-1.5^{\circ} \mathrm{C}\right.$ to $-0.5^{\circ} \mathrm{C}$ every $\left.0.5^{\circ} \mathrm{C}\right)$ shown by the thick (thin) white line. (j) $\mathrm{S}_{\mathrm{A}}$ with isoline of $34.83 \mathrm{~g} \mathrm{~kg}^{-1}\left(34.5 \mathrm{~g} \mathrm{~kg}^{-1}\right.$ to $34.8 \mathrm{~g} \mathrm{~kg}^{-1}$ every $0.1 \mathrm{~g} \mathrm{~kg}^{-1}$ ) shown by the thick (thin) white line. (k) $\gamma^{\mathrm{n}}$ with isoline of $28.0 \mathrm{~kg} \mathrm{~m}^{-3}\left(28.1 \mathrm{~kg} \mathrm{~m}^{-3}\right.$ and $\left.28.2 \mathrm{~kg} \mathrm{~m}^{-3}\right)$ shown by the thick (thin) white line. (l) Dissolved oxygen (DO; $\left.\mathrm{mL} \mathrm{L}^{-1}\right)$ with isoline of $5.5 \mathrm{~mL} \mathrm{~L}^{-1}\left(5 \mathrm{~mL} \mathrm{~L}^{-1}\right.$ to $7 \mathrm{~mL} \mathrm{~L}^{-1}$ every $\left.1 \mathrm{~mL} \mathrm{~L}^{-1}\right)$ shown by the thick (thin) white line. Contrarily to Figure 9, this figure was created by simply selecting the nearest grid points to the sections, due to the limited amount of data in other seasons except summer. 

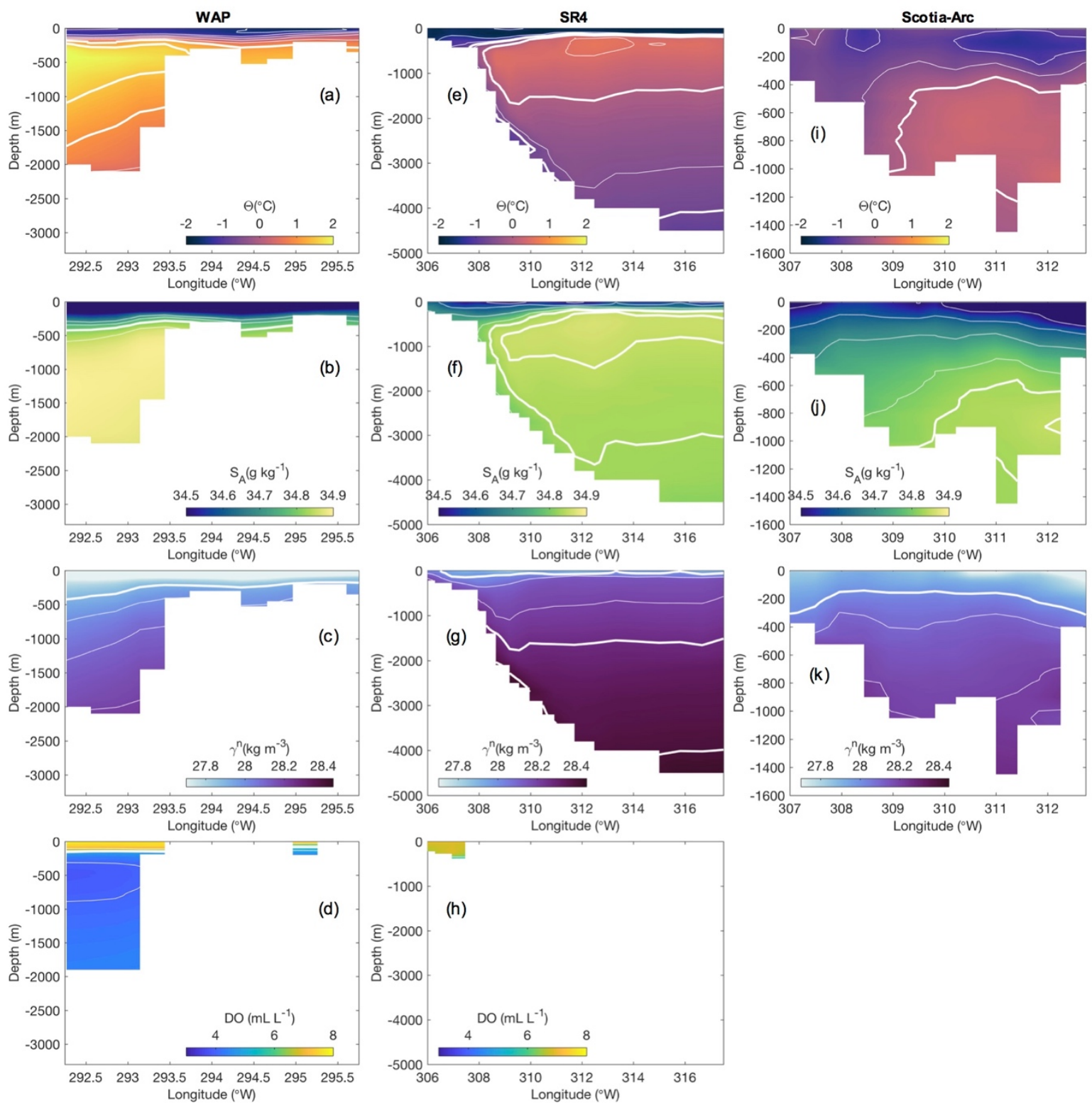

Figure S13. Spring vertical sections along the Western Antarctic Peninsula (WAP; a-d; magenta line in Fig. 1a), WOCE SR4 across the Weddell Gyre (e-h; green line in Fig. 1a), and Scotia-Arc line over the South Scotia Ridge (i-k; cyan line in Fig. 1a). (a) Conservative temperature $\left(\Theta ;{ }^{\circ} \mathrm{C}\right)$ with isotherms of $1{ }^{\circ} \mathrm{C}$ and $1.5^{\circ} \mathrm{C}\left(-1.5^{\circ} \mathrm{C}\right.$ to $0.5^{\circ} \mathrm{C}$ every $\left.0.5^{\circ} \mathrm{C}\right)$ shown by the thick (thin) white line. (b) Absolute salinity $\left(\mathrm{S}_{\mathrm{A}} ; \mathrm{g} \mathrm{kg}^{-1}\right)$ with isoline of $34.8 \mathrm{~g} \mathrm{~kg}^{-1}\left(34.7 \mathrm{~g} \mathrm{~kg}^{-1}\right.$ to $34.85 \mathrm{~g} \mathrm{~kg}^{-1}$ every $\left.0.05 \mathrm{~g} \mathrm{~kg}^{-1}\right)$ shown by the thick (thin) white line. (c) Neutral density $\left(\gamma^{\mathrm{n}} ; \mathrm{kg} \mathrm{m}^{-3}\right)$ with isoline of $27.9 \mathrm{~kg} \mathrm{~m}^{-3}\left(28.0 \mathrm{~kg} \mathrm{~m}^{-3}\right.$ to $28.2 \mathrm{~kg} \mathrm{~m}^{-3}$ every $0.1 \mathrm{~kg} \mathrm{~m}^{-3}$ ) shown by the thick (thin) white line. (d) Dissolved oxygen (DO; $\mathrm{mL} \mathrm{L}^{-1}$ ) with isoline of $5.5 \mathrm{~mL} \mathrm{~L}^{-1}(4 \mathrm{~mL}$ $\mathrm{L}^{-1}$ to $7 \mathrm{~mL} \mathrm{~L}^{-1}$ every $\left.1 \mathrm{~mL} \mathrm{~L}^{-1}\right)$ shown by the thick (thin) white line. (e) $\Theta$ with isotherms of $-0.7^{\circ} \mathrm{C}$ and $0^{\circ} \mathrm{C}\left(-1.5^{\circ} \mathrm{C}\right.$ to $0.5^{\circ} \mathrm{C}$ every $0.5^{\circ} \mathrm{C}$ ) shown by the thick (thin) white line. (f) $\mathrm{S}_{\mathrm{A}}$ with isolines of $34.83 \mathrm{~g} \mathrm{~kg}^{-1}$ and $34.85 \mathrm{~g} \mathrm{~kg}^{-1}\left(34.5 \mathrm{~g} \mathrm{~kg}^{-1}\right.$ to $34.8 \mathrm{~g}$

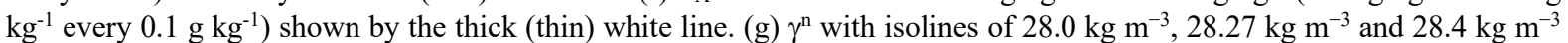
$\left(28.1 \mathrm{~kg} \mathrm{~m}^{-3}\right.$ and $28.2 \mathrm{~kg} \mathrm{~m}^{-3}$ ) shown by the thick (thin) white line. (h) Dissolved oxygen (DO; $\mathrm{mL} \mathrm{L}^{-1}$ ) with isoline of 5.5 $\mathrm{mL} \mathrm{L}^{-1}\left(6 \mathrm{~mL} \mathrm{~L}^{-1}\right)$ shown by the thick (thin) white line. (i) $\Theta$ with isotherms of $0^{\circ} \mathrm{C}\left(-1.0^{\circ} \mathrm{C}\right.$ and $\left.-0.5^{\circ} \mathrm{C}\right)$ shown by the thick (thin) white line. (j) $\mathrm{S}_{\mathrm{A}}$ with isoline of $34.83 \mathrm{~g} \mathrm{~kg}^{-1}\left(34.5 \mathrm{~g} \mathrm{~kg}^{-1}\right.$ to $34.8 \mathrm{~g} \mathrm{~kg}^{-1}$ every $\left.0.1 \mathrm{~g} \mathrm{~kg}^{-1}\right)$ shown by the thick (thin) white line. (k) $\gamma^{\mathrm{n}}$ with isoline of $28.0 \mathrm{~kg} \mathrm{~m}^{-3}\left(28.1 \mathrm{~kg} \mathrm{~m}^{-3}\right.$ and $\left.28.2 \mathrm{~kg} \mathrm{~m}^{-3}\right)$ shown by the thick (thin) white line. Contrarily to Figure 9 , this figure was created by simply selecting the nearest grid points to the sections, due to the limited amount of data in other seasons except summer. 

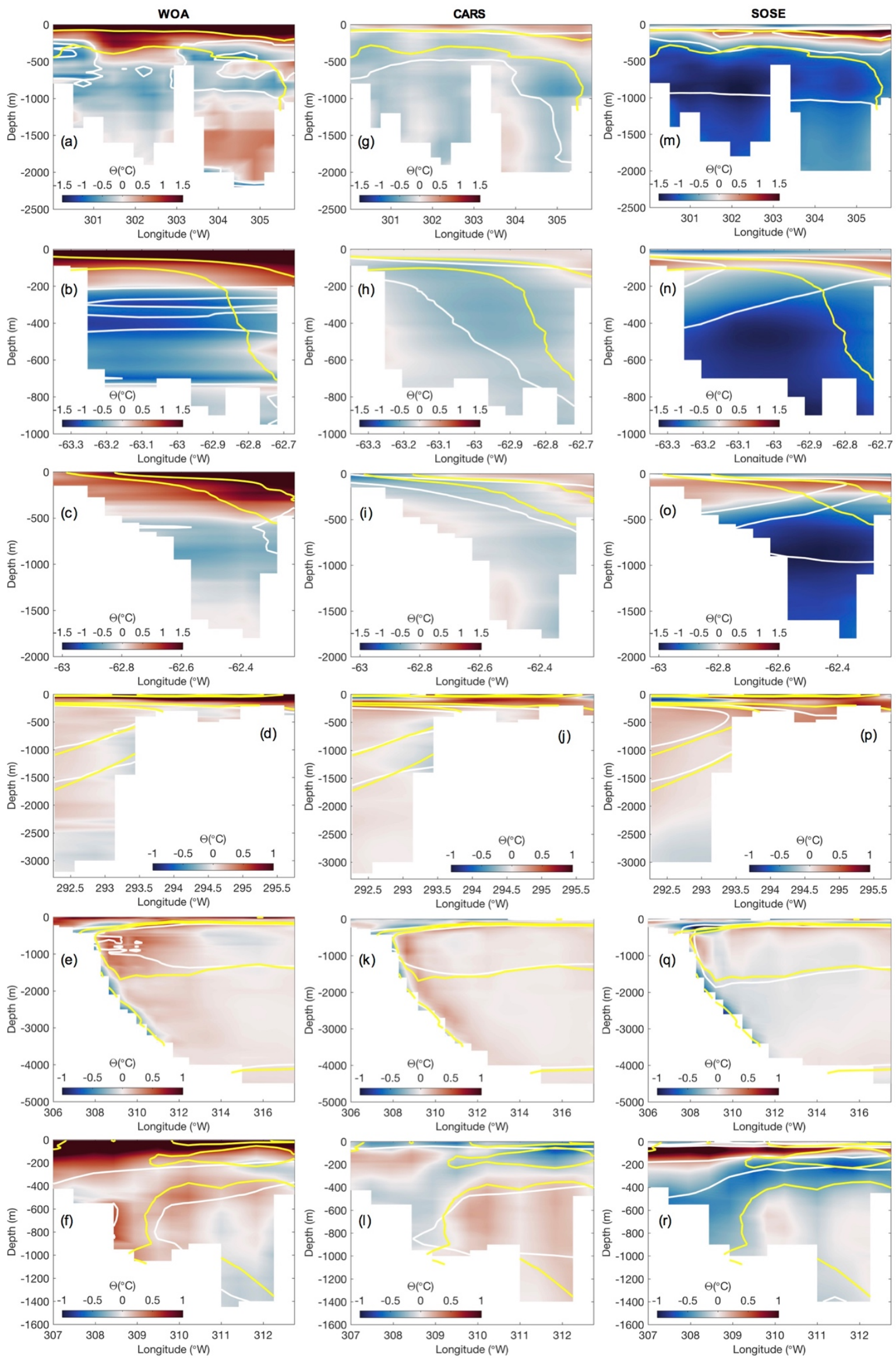

Figure S14. Conservative temperature $\left(\Theta ;{ }^{\circ} \mathrm{C}\right)$ difference between NAPv1.0 minus WOA (left panels), CARS (middle panels) and SOSE (right panels) for summer season. $(\mathrm{a}, \mathrm{g}, \mathrm{m})$ Sections along the Bransfield Strait. $(\mathrm{b}, \mathrm{h}, \mathrm{n})$ Sections between Livingston 
Island and the Antarctic Peninsula. (c, i, o) Sections between King George Island and the Antarctic Peninsula. For panels (a, $\mathrm{b}, \mathrm{c}, \mathrm{g}, \mathrm{h}, \mathrm{i}, \mathrm{m}, \mathrm{n}$ and o) isotherms of $0^{\circ} \mathrm{C}$ and $-0.7^{\circ} \mathrm{C}$ are shown for NAPv1.0 (yellow) and the other climatologies (white). (d, j, p) Sections at the WAP. (e, k, q) Sections WOCE SR4. (f, l, r) Sections Scotia-Arc. For panels (a, b, c, e, f, g, h, i, k, 1, m, n, $\mathrm{o}, \mathrm{q}$ and $\mathrm{r}$ ) isotherms of $0^{\circ} \mathrm{C}$ and $-0.7^{\circ} \mathrm{C}$ are shown for NAPv1.0 (yellow) and the other climatologies (white). For panels (d,j and $\mathrm{p}$ ) isotherms of $1^{\circ} \mathrm{C}$ and $1.5^{\circ} \mathrm{C}$ are shown for NAPv1.0 (yellow) and the other climatologies (white). 

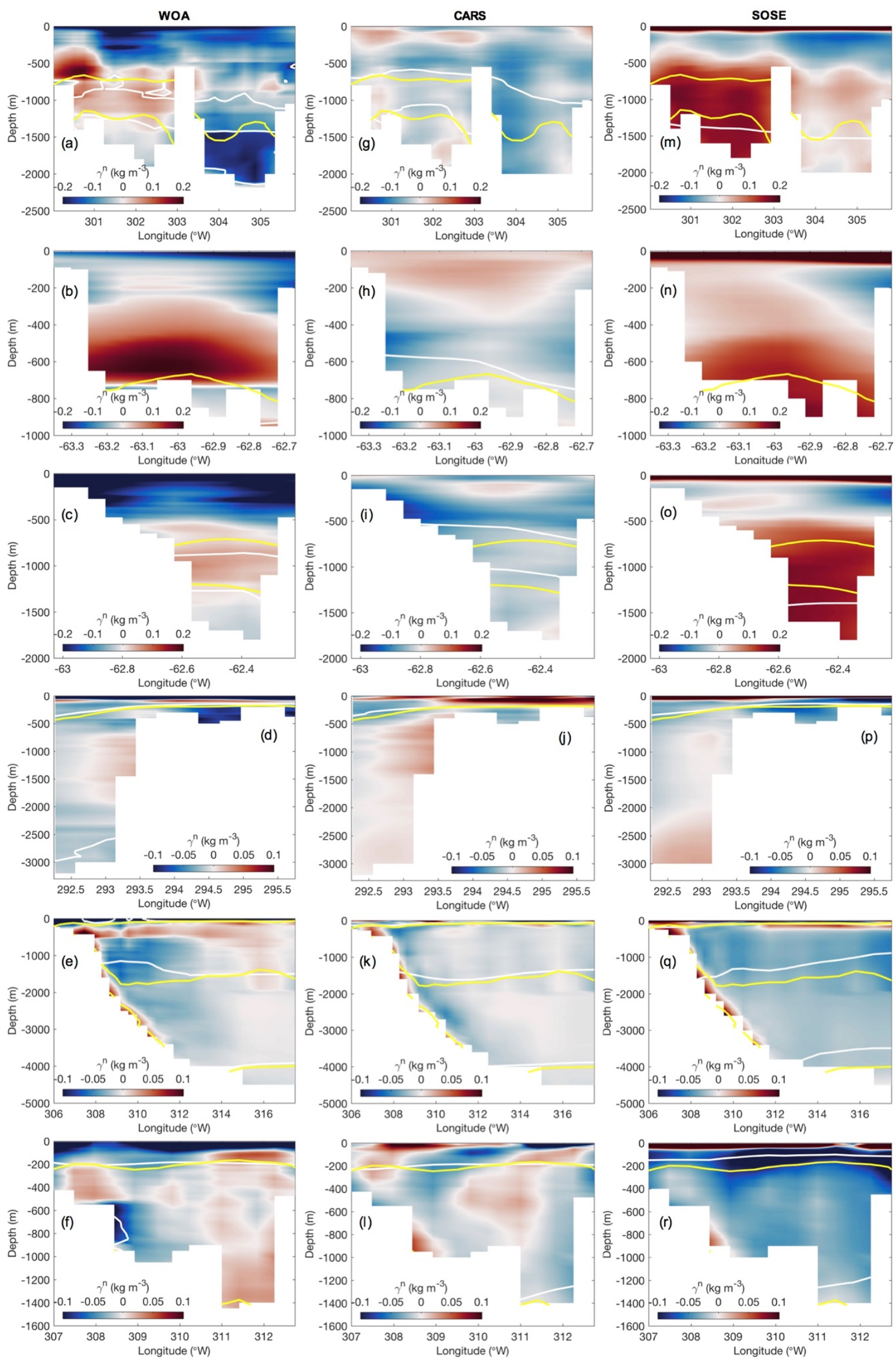

Figure S15. Neutral density $\left(\gamma^{\mathrm{n}} ; \mathrm{kg} \mathrm{m}^{-3}\right)$ difference between NAPv1.0 minus WOA (left panels), CARS (middle panels) and SOSE (right panels) for summer season. (a, g, m) Sections along the Bransfield Strait. (b, $h, n)$ Sections between Livingston 
Island and the Antarctic Peninsula. (c, i, o) Sections between King George Island and the Antarctic Peninsula. For panels (a, $\mathrm{b}, \mathrm{c}, \mathrm{g}, \mathrm{h}, \mathrm{i}, \mathrm{m}, \mathrm{n}$ and o) isotherms of $0^{\circ} \mathrm{C}$ and $-0.7^{\circ} \mathrm{C}$ are shown for NAPv1.0 (yellow) and the other climatologies (white). (d, j, p) Sections at the WAP. (e, k, q) Sections WOCE SR4. (f, l, r) Sections Scotia-Arc. For panels (a, b, c, g, h, i, m, n and o) isopycnals of $28.27 \mathrm{~kg} \mathrm{~m}^{-3}$ and $28.40 \mathrm{~kg} \mathrm{~m}^{-3}$ are shown for NAPv1.0 (yellow) and the other climatologies (white). For panels ( $\mathrm{d}, \mathrm{j}$ and $\mathrm{p}$ ) isopycnals of $27.9 \mathrm{~kg} \mathrm{~m}^{-3}$ and $28.27 \mathrm{~kg} \mathrm{~m}^{-3}$ are shown for NAPv1.0 (yellow) and the other climatologies (white). For panels (e, $\mathrm{k}$ and $\mathrm{k}$ ) isopycnals of $28 \mathrm{~kg} \mathrm{~m}^{-3}, 28.27 \mathrm{~kg} \mathrm{~m}^{-3}$ and $28.40 \mathrm{~kg} \mathrm{~m}^{-3}$ are shown for NAPv1.0 (yellow) and the other climatologies (white). For panels (f, 1 and r) isopycnals of $28 \mathrm{~kg} \mathrm{~m}^{-3}$ and $28.27 \mathrm{~kg} \mathrm{~m}^{-3}$ are shown for NAPv1.0 (yellow) and the other climatologies (white). 